Canadian

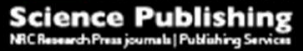

Botany

Botanique

The role of mycorrhizal symbioses in phytotechnology

\begin{tabular}{|r|l|}
\hline Journal: & Botany \\
\hline Manuscript ID & cjb-2017-0032.R2 \\
\hline Manuscript Type: & Review \\
\hline Date Submitted by the Author: & 23-May-2017 \\
\hline $\begin{array}{r}\text { Complete List of Authors: } \\
\text { Is the invited manuscript for } \\
\text { consideration in a Special } \\
\text { Issue? : }\end{array}$ & $\begin{array}{l}\text { Chagnon, Pierre-Luc; Institut de recherche en biologie vegetale, } \\
\text { Brisson, Jacques; Institut de recherche en biologie vegetale, Département } \\
\text { des Sciences Biologiques, Université de Montréal }\end{array}$ \\
\hline Keyword: & $\begin{array}{l}\text { Phytoremediation, Green roofs, Treatment wetlands, Ecological restoration, } \\
\text { Constructed wetlands }\end{array}$ \\
\hline \multicolumn{2}{|c}{} \\
\hline \multicolumn{2}{|c}{}
\end{tabular}




\section{The role of mycorrhizal symbioses in phytotechnology}

2

3 Chagnon, P.L., Brisson, J.

4

5 Affiliations :

6

7 Chagnon, P.L.

8 Institut de Recherche en Biologie Végétale, Département de sciences biologiques,

9 Université de Montréal, 4101 Sherbrooke E, Montréal, H1X 2B2, pierre-

10 luc.chagnon@umontreal.ca

12 Brisson, $\mathrm{J}$.

13 Institut de Recherche en Biologie Végétale, Département de sciences biologiques,

14 Université de Montréal, 4101 Sherbrooke E, Montréal, H1X 2B2,

15 jacques.brisson@umontreal.ca

16

17

18 Corresponding author : Pierre-Luc Chagnon; tel. 514-343-2078

19

20 


\section{Abstract}

There is a growing interest in using plants to provide low-cost ecosystem services in a

23 diversity of environments (e.g., polluted, degraded, urban). These utilizations of

24 plants are collectively referred to as phytotechnologies. Many plants used in

25 phytotechnological applications are naturally found to associate with mycorrhizal

26 fungi. These fungal associates can provide numerous ecosystem services, or help

27 plants to do so. There is thus an obvious incentive to better understand how

28 mycorrhizal symbioses can assist phytotechnologies. For some phytotechnological

29 applications, the benefits of using mycorrhizal fungi seem well established while for

30 others, these benefits are either uncertain or simply unexplored. In all cases, a trait-

31 based, mechanistic understanding of what allows mycorrhizal fungi to provide any

32 benefit/service is urgently needed. This will help to develop reliable, mycorrhizas-

33 assisted phytotechnologies in the future, while also improving our fundamental

34 understanding of the evolution of stress tolerance in these important plant-associated 35 symbionts.

40 Keywords: phytoremediation, phytostabilization, green roofs, pollution, treatment

41 wetlands, constructed wetlands, ecological restoration. 
42 In the last two or three centuries, the rapid development of urban centers, and more

43 recently the intensification of agricultural practices, have given rise to a myriad of

44 environmental issues. These include the pollution of soils with heavy metals and

45 organic compounds, the loss of soil structure, and the increase in wastewater

46 volumes. Phytotechnology is a domain of applied science and engineering that

47 focuses on the use of plants to provide cost-effective, sustainable solutions to these

48 environmental issues (Mangkoedihardjo 2007). Treatment (or constructed) wetlands,

49 soil phytoremediation, green roofs and green stormwater facilities are all examples of

50 phytotechnological approaches. Although phytotechnologies are plant-based systems,

51 their driving mechanisms often involve microbial processes taking place in the

52 rhizosphere. Among the plants' microbial associates, mycorrhizal fungi (MF) are

53 especially important, as they can receive up to $20 \%$ of plants' photosynthates and

54 constitute around the third of soil microbial biomass (Leake et al. 2004). In the

55 context of phytotechnology, MF can alleviate plant stress through a wide variety of

56 mechanisms, including the provision of growth-limiting nutrients, the alteration of the

57 host hormonal balance and the sequestration of heavy metals in the soil. This allows

58 plants to provide more efficiently some key phytotechnological services. Also, MF

59 can provide by themselves some services, for example by ameliorating soil structure

60 (Kohler et al. 2017). However, for many phytotechnological applications, the role of

61 MF remains unclear, either because it has only been rarely investigated (e.g., green

62 roofs) or because it is expected to have little influence (e.g., treatment wetlands

63 dealing with nutrient-rich wastewaters, considering that MF typically reduce in

64 abundance in nutrient-rich systems [Smith and Read 2008]). Here, we broadly review 
65 the empirical evidence that MF can influence the success of phytotechnologies. We

66 also identify key traits of MF that are likely to promote specific phytotechnological

67 applications. We focus our review on four of the most familiar phytotechnologies: (1)

68 phytoremediation, (2) stabilization of degraded soils, (3) treatment wetland, and (4)

69 green roofs and green walls (Table 1).

\section{Phytoremediation}

72 Contamination of soils with toxic compounds such as heavy metals or oil products is

73 a pervasive environmental problem (Varkey et al. 2012). These contaminants are

74 associated with a variety of human activities such as mining, combustion of fossil

75 fuels, and the application of pesticides in agriculture (Clemens 2006). Their

76 accumulation in the environment represents a hazard to human health, and also

77 compromises plant and microbial growth. However, their removal from soils is often

78 very costly, such that large contaminated areas often cannot be remediated through

79 chemical extraction. The use of plants to either stabilize, volatilize or extract these

80 inorganic or organic pollutants (referred to as phytoremediation), on the other hand,

81 may represent a cost-effective way to ameliorate soil conditions.

83 For phytoremediation of heavy metals, many studies have aimed at identifying plants

84 that can both (1) tolerate high soil metal concentrations and (2) produce large

85 amounts of biomass where heavy metals can be highly concentrated (the so-called

86 "hyperaccumulators") (Gamalero and Glick 2012). However, a large amount of 
87 research trying to identify metal-accumulating plants focused on Brassica, a plant 88 genus that does not form symbiotic associations with MF. Yet, MF could be expected 89 to increase the efficiency of phytoremediation practices, in various ways (reviewed in 90 Hassan et al. 2010). For example, arbuscular mycorrhizal (AM) fungi have sometimes 91 been shown to promote the immobilization of metals in soil (Wu et al. 2016), which 92 could be explained by the binding of heavy metal cations to (1) cell wall components 93 (i.e., glomalin; Gonzalez-Chavez et al. 2004; Wu et al. 2014) or (2) vacuolar 94 polyphosphates bearing negative charges (Leung et al. 2013). Janouskova et al. 95 (2006) showed, in fact, that extraradical hyphae of some AM fungi could be up to 20 96 times more efficient in binding Cadmium $(\mathrm{Cd})$ than tobacco roots. Joner et al. (2000) 97 also showed that AM fungal strains isolated from sites polluted with heavy metals 98 were even more efficient at binding $\mathrm{Cd}$ and $\mathrm{Zn}$ on their hyphae than strains isolated 99 from unpolluted environments. Other studies have also found that AM fungi could 100 prevent the translocation of metals from roots to shoots (Marques et al. 2007; Affholder et al.2014), which can be due to the accumulation of metals bound to plant cell walls (Almeida-Rodriguez et al. 2016). Similarly to AM fungi, some ectomycorrhizal (ECM) and ericoid mycorrhizal (ERM) fungi have also been shown 104 to protect plants from heavy metals through various mechanisms (Colpaert et al. 105 2011; Daghino et al. 2016), including the sorption to cell wall components, the 106 segregation into cellular structures, or the chelation in the cytosol by metallothioneins 107 (Nguyen et al. 2017). 
Regarding the impact of MF on net metal uptake, empirical evidence is mixed, some studies showing that MF could acidify neighbouring soil and promote solubilisation and uptake of metals (Leyval and Joner 2001), and others showing that metal uptake could be reduced by MF, thus reducing toxicity to plants (Wang et al. 2007). We still need to clarify what mycorrhizal fungal traits are important to influence metal uptake.

114 For example, many studies have shown that MF could promote rock weathering through the production of organic acids (ectomycorrhizal fungi: Jongmans et al. 1997; Quirk et al. 2014; Schmalenberger et al. 2016 / arbuscular mycorrhizal fungi: Burghela et al. 2015): these could also solubilize heavy metals or other toxic elements. For example, organic acids can complex with $\mathrm{Al}$ and reduce its toxicity (Seguel et al. 2013). Mycorrhizal fungi can also produce chelating, metal-binding agents (Haselwandter et al. 2006; Winkelmann et al. 2007) or promote the growth of siderophore-producing bacteria in their hyphosphere (Franco-Correa et al. 2010). These traits, and potentially others as well (see Hassan et al. 2010), could be linked to increased metal uptake and transfer to plants. More work will thus be needed to evaluate the net impact of MF on the phytoextraction of metals. Even if MF often increase metal tolerance of hosts, if they accomplish this through reduced uptake of metals, or reduced transfer to hosts, then the goal of phytoextraction is not met (provided that the goal is to extract, and not only stabilize, metals). On the other hand, it must be noted that even if MF reduce metal uptake by the plant (thus reducing metal concentration per unit of plant tissue), the total amount of metal extracted from the soil can still be increased by MF if mycorrhizal plants produce much more biomass overall, as it is often seen in stressful environments (Smith and Read 2008). 
Phytoremediation also addresses the role of plants in detoxifying soils contaminated with persistent organic pollutants (POPs, e.g., polychlorinated biphenyls [PCB], dichlorodiphenyltrichloroethane [DDT]) (Infante et al. 2012). Here, the role of plants is rather to promote the activity of soil microbes having the ability to degrade these organic compounds. It is expected that root exudates can promote the growth of POPdegrading microbes, since those exudates can provide a labile carbon (C) source and sometimes a N source to support microbial metabolism (Alkorta and Garbisu 2001). can strongly prime the decomposition of soil organic matter; they could therefore prime the degradation of POPs through similar mechanisms. Moreover, AM fungi have been shown to modify plant exudates (e.g., Hage-Ahmed et al. 2013), which could indirectly influence, and potentially promote, POP-degrading microbial populations. This is consistent with the study published by Corgié et al. (2006), showing increased population sizes of POP-degrading culturable bacteria in soils colonized by AM roots. MF may also directly influence POP degradation through their own enzyme secretion. For example, ECM and ERM fungi are known to express 
laccases (Burke and Cairney 2002), which can attack organic matter through

156 oxidative mechanisms (Lindhal and Tunlid 2015): these could thus break down POPs

157 more specifically. Accordingly, several studies using pure liquid ECM fungal cultures

158 have found them to be sometimes almost as efficient as white rot fungi, which are

159 well known to oxidize soil organic matter (e.g., Braun-Lülleman et al. 1999).

160 Regarding AM fungi, several genes in the genome of the model species Rhizophagus

161 irregularis have been identified as potentially associated with POPs degradation

162 (Lenoir et al. 2016). However, some studies have shown that MF can in fact delay

163 organic matter decomposition (e.g., ECM fungi: Gadgil and Gadgil 1971 /AM fungi:

164 Verbruggen et al. 2016), and more specifically POP degradation (Genney et al. 2004),

165 which could be explained by competitive/antagonistic interactions between MF and 166 other soil microorganisms.

Future work addressing the potential for MF to assist phytoremediation of sites contaminated with heavy metals or POPs should aim at identifying the fungal traits associated with increased remediation (Table 1). For example, tropical grasses producing large amounts of thin roots have been shown to better promote POPs

172 breakdown in their rhizosphere in a greenhouse assay (Merkl et al. 2005). Likewise, 173 similar studies must identify what traits best promote the phytoremediation potential 174 of MF, which is known to vary among species (Liu and Dalpé 2009; Hassan et al. 175 2013). Since local, stress-adapted strains of MF have often been shown to be more 176 effective to remove contaminants or at least promote plant growth in stressful 177 environments (e.g., Cabello et al. 1999; Joner et al. 2000; Vivas et al. 2006; Lacercat- 
178 Didier et al. 2016), comparing the traits of these strains to the traits of strains from 179 nearby, unpolluted environments may be a useful starting point. Indeed, it has been 180 shown several times that polluted soil can retain a high diversity of AM fungi (e.g., de 181 la Providencia et al. 2015), although these communities are often dominated by 182 closely related members of specific families (Hassan et al. 2014; de la Providencia et 183 al. 2015; Krishnamoorthy et al. 2015), which further suggests that key traits favor the success of MF in such stressful habitats (see Hassan et al. 2010). Other studies have found that organic contaminant spills decreased ECM fungal community diversity, retaining only (and potentially favouring) strains that were resistant to the pollutant (Nicolotti and Egli 1998). The nature of these resistance traits still remains elusive. They may relate to changes in enzyme secretion, or membrane or cell wall composition, but may also be behavioural. For example, since POPs may harm fungal membranes (Robertson et al. 2007), they could be expected to favour more intraradical biomass production, at the expense of less soil hyphal biomass. However,

197 their mycorrhizal symbionts may thus strongly decrease their fitness. The upcoming 198 challenges are thus to (1) clarify what fungal traits favour their resistance to environmental contaminants and (2) evaluate whether resistance-traits make MF more 
200 or less efficient in dissipating these contaminants, either through direct removal or 201 through altered plant performance.

\section{Stabilization of degraded soils}

204 Human activities worldwide greatly contribute to soil erosion and loss of structure

205 (Pimentel et al. 1995). A major cause for increased slope instability or soil erosion is

206 the loss of plant cover (Auzet et al. 2006), and various approaches and technologies

207 have been developed to limit soil erosion by re-establishing vegetation and applying

208 various amendments to the soil (Blanco-Canqui and Lal 2010). It has been shown that

209 an efficient management of degraded soils can reduce soil erosion by a factor of 50

210 (de Santisteban et al. 2006). MF are known to ameliorate soil structure in various

211 ways, including shifts in host root system architecture, enmeshment of soil particles

212 with hyphae and changes in soil moisture regimes (Rillig and Mummey 2006).

213 However, plant and fungal species vary substantially in their effect on soil

214 aggregation (e.g., Rillig et al. 2002; Piotrowski et al. 2004). We still lack a predictive

215 framework linking root and hyphal traits to soil structure (Rillig et al. 2015).

216 However, through a meta-analysis, Leiheit et al. (2015) have identified in what

217 experimental conditions AM fungi have been found to be most efficient in promoting

218 soil aggregation: they reported, for example, that AM fungi were more likely to

219 improve soil structure in pot studies with near neutral soil $\mathrm{pH}$. Such analyses,

220 combined with additional experimental work, will provide some guidelines regarding

221 the environmental conditions where MF are expected to be most useful in soil

222 conservation and management practices. But as stressed by Rillig et al. (2015), there 
223 is a need to develop a trait-based framework in order to predict the ability of various

224 MF (both AM and ECM) to improve soil structure (Table 1). The authors highlighted

225 traits for further investigation such as hyphal length density or growth rate, as well as

226 longevity. We could add to this list traits related to the amount of C transferred by

227 MF to soil bacteria: the latter are expected to stabilize microaggregates (Tisdall

228 1994). It would also be valuable to investigate how shifts in root system architecture

229 due to root colonization by MF influence soil aggregation: the reduced specific root

230 length and branching intensity found in some colonized plants (e.g., Hetrick et al.

231 1988) could in fact reduce the positive impact of roots on soil aggregation.

233 We also need to gather data about trait-environment linkages. When developing 234 mycorrhizal fungal inocula (AM, ECM or ERM) for application in soil restoration 235 projects, it is not only important to select and multiply fungal species with optimal 236 traits: we need to ensure that our inocula will perform well under the environmental 237 conditions where they will be applied. Such knowledge about trait-environment 238 relationships is especially scarce in the mycorrhizal literature. There are some data 239 linking, for example, spore size and phenology to disturbance regimes (e.g., Oehl et 240 al. 2009), but regarding traits of interest in the context of soil aggregation (see Rillig 241 et al. 2015), virtually nothing is known. Data on trait-environment relationships 242 would also be useful in situations where fungal inoculation is hardly feasible: it could 243 rather be envisaged to apply various amendments to modify the abiotic environment 244 in a way that is expected to favor specific, desired fungal traits. For example, if high 245 soil hyphal biomass is a desirable trait in a given applied context, applying $\mathrm{N}$ 
246 fertilizers may promote a P limitation of some AM fungi that will favour their soil

247 hyphal biomass production (Johnson et al. 2003).

249 Similar data are also needed to evidence linkages between plant and fungal traits. To 250 quickly restore a dense vegetation cover that will efficiently ameliorate soil structure, 251 we need to apply optimal mixtures of plants and mycorrhizal fungal species. It has 252 been shown that soil-based inocula can influence our success in establishing a target 253 vegetation (Middleton and Bever 2012). Likewise, various methods to establish a 254 plant cover differentially impact the AM fungal community: van de Voorde et al. 255 (2010) found that sowing plant communities (compared to unsown communities 256 relying on plant propagule bank) led to more spatially homogeneous AM fungal 257 communities (i.e., reduced beta-diversity). Future research will have to dissect these 258 community-level patterns to evidence linkages between plant and fungal traits. For 259 example, Chagnon et al. (2015) have sampled young regenerating forests, and 260 correlated plant traits to the identity of their AM fungal partners. They found that 261 plants with resource-conservative leaf traits (e.g., Spiraea alba var. latifolia having 262 high leaf dry mass content) associated with different AM fungi as compared to plants 263 with resource-acquisitive traits (e.g., Clematis virginiana having high specific leaf 264 area). The next frontier will be to ask what fungal traits are promoted in the 265 rhizosphere of a plant bearing specific root traits, and vice versa. Better understanding 266 the linkages between the traits of plants and their mycorrhizal symbionts will help to 267 design specific plant-fungal mixtures that are most efficient in restoring structure in 268 degraded soils. 


\section{3 . Treatment wetlands}

272 Treatment wetlands (TW), also known as "constructed wetlands", are artificial

273 wetlands that can be designed to treat a variety of water types (e.g., agricultural

274 runoff, industrial contaminated water, domestic wastewater) in order to improve its

275 quality (e.g., by removing pollutants, nutrients and/or dissolved organic matter). Their

276 use has increased tremendously since the 1990's, as there were some clear examples

277 of successful implementations of this phytotechnology over the years. For example,

278 TW were established under a cold climate in Norway in order to treat domestic

279 wastewaters, and they allowed the reduction of BOD (biological oxygen demand,

280 which is the oxygen required by aerobic organisms to degrade the organic matter in a

281 water body) of these wastewaters by $90 \%$ (Paruch et al. 2016). TW, at least those

282 referred to as "sub-surface", are typically planted with large aquatic plants such as

283 reed (Phragmites australis) and cattails (Typha spp.), which produce large amounts of

284 roots and rhizomes (Brisson and Chazarenc 2009; Vymazal 2011). It is often assumed

285 that pollutant removal efficiency in TW is correlated with enhanced plant (especially

286 root) biomass production. It is also recognized that transformation and removal of

287 most pollutants in TW is primarily due to bacterial activity (Faulwatter et al. 2009).

289 Now, can MF be of any help here? The soil environment in TW is typically very

290 nutrient rich, especially TW receiving domestic wastewater, and the rhizosphere

291 environment is flooded or highly humid. Both AM and ECM fungi are well known to 
292 decrease in abundance in fertile systems (e.g., Smith and Read 2008; Bahr et al.

293 2013), and there is some evidence that low oxygen pressure is also detrimental to AM

294 fungi (Le Tacon et al. 1983). On the other hand, some AM fungi are known to persist

295 in fertile soils (e.g., Johnson et al. 1993) and poorly oxygenated substrates such as

296 peat bogs (Thormann 2006). In surveys of natural wetland plants, symbioses with AM

297 fungi have been found to be the norm rather than the exception (extensively reviewed

298 by $\mathrm{Xu}$ et al. 2016). Moora et al. (2016) also have found that AM fungi colonizing the

299 roots of a submerged aquatic plant comprised a high proportion of novel taxa and a

300 non-random subsample of already known taxa, suggesting that AM fungi growing in

301 these habitats may bear specific traits allowing them to adapt to such unique

302 conditions.

303

304 Likewise, in a TW, Fester (2013) found extensive AM fungal colonization, and

305 molecular analyses revealed that the community was largely dominated by generalist

306 taxa recognized as ruderals (e.g., Funneliformis mosseae and Rhizophagus

307 irregularis, Chagnon et al. 2013). This suggests that in the context of TW, AM fungi

308 could be expected to successfully colonize plants and potentially favor their growth.

309 In fact, Lingua et al. (2015) did find that AM fungal inoculation improved $\mathrm{NO}_{3}{ }^{-}$

310 removal from wastewaters. However, other reports from natural wetlands or TW

311 suggested that AM fungal abundance could decrease due to flooding (Cantelmo and

312 Ehrenfeld 1999), high water P concentrations (Cornwell et al. 2001; Wang et al.

313 2014) or high organic matter content (Confer and Niering 1992). Some studies have

314 also shown a decrease in arbuscule formation as compared to other fungal structures 
315 in flooded and high-nutrient wetlands or TW (e.g., Cantelmo et al. 1999; Wang et al.

316 2014; but see Miller et al. 2000). Given that the arbuscules are the main site of

317 nutrient delivery to plants in the AM symbiosis (Smith and Read 2008), these results

318 might suggest that in natural wetlands or in TW, the main function of the symbiosis

319 shifts from nutrition to, for example, pathogen protection. Little is known about the

320 accumulation of root pathogens by TW plants, but we know that some AM fungi can

321 be very efficient at protecting their hosts against pathogens (e.g., Sikes et al. 2009).

323 Overall, empirical assessment of the presence, the importance or even the role of MF

324 in TW remains scarce in the literature. Future work will be required to better evaluate

325 their importance, quantify their impact on plant growth and functioning, and elucidate

326 traits which allow MF to persist in TW (Table 1). We could then envisage the

327 development of inoculation strategies aimed at introducing TW fungal strains that

328 either possess traits that favor a given ecosystem service (e.g., larger hyphal networks

329 stabilizing contaminated sediments) or traits that better promote the growth of plants,

330 which can in turn provide services through their own root systems. For example,

331 plants can provide a substrate and exudates to support microbial biofilm formation

332 and metabolic activity (Brix 1997), or take up nutrients from eutrophicated waters.

333 However, compelling evidence that MF do provide benefits in TW must first be

334 produced.

335

336 4. Green roofs and walls 
337 Green roofs have recently emerged as a promising phytotechnology providing, in

338 urban ecosystems, a variety of benefits including the reduction of stormwater outputs

339 through roof leachates and the regulation of building temperatures (Oberndorfer et al.

340 2007). Likewise, green or vegetated walls can also help to regulate indoor building

341 temperatures: Hoyano (1988) found that vegetated walls could reduce indoor air

342 temperature by $7^{\circ} \mathrm{C}$. However, green roofs and walls present unique challenges to

343 plants, namely a thin substrate and a strong exposure to winds (Sutton 2015). This can

344 make plants highly susceptible to drought. AM fungi are well-known to ameliorate

345 water relations in plants, through various mechanisms (reviewed in Augé 2001),

346 including regulation of stomatal closure and hormonal balance. However, there is

347 large interspecific variation in the ability of AM fungi to improve plant water

348 relations (Dixon et al. 1994; Mathur and Vyas 1995). As for the effect of MF on soil

349 aggregation, we still lack a mechanistic understanding of the fungal traits responsible

350 for the amelioration of plant water relations. The best MF could be those that possess

351 the finest hyphae, able to reach water in finer micropores (Drew et al. 2003).

352 Alternatively, the ability for MF to alter the host hormonal balance (e.g., abscisic acid

353 production) and thus trigger a better plant response to drought could be another key

354 trait to investigate (Estrada-Luna and Davies 2003). Comparative studies linking

355 mycorrhizal fungal traits to amelioration of plant response to drought will be required

356 to identify and select optimal fungal strains that may be used as inoculum in green

357 roofs and walls. Knowledge advancement on how MF traits favour drought tolerance

358 would also be useful to the study of POP-contaminated sites, which are also known to

359 lose a large part of their water retention capacity (Robertson et al. 2007). 
361 Another benefit that could be provided by MF in such phytotechnologies relates to 362 the cycling of organic matter. In most installations, the substrate used for green roofs 363 and walls is highly organic (e.g., coco husk, peat moss) for two reasons: it is 364 lightweight and it provides a nutrient reserve made available progressively through 365 mineralization (Sutton 2015). However, the low clay content of such substrates 366 reduces their water retention, which can limit nutrient mineralization. The ability of 367 some MF to prime organic matter decomposition (Paterson et al. 2016) or at least 368 scavenge for nutrient mineralized by saprotrophs or soil fauna (e.g., Leigh et al. 2009; 369 Koller et al. 2013), could promote nutrient transfer to plants. On the other hand, MF 370 have also been shown to sometimes reduce organic matter decomposition (e.g., 371 Verbruggen et al. 2016), which could be due to antagonistic interactions between MF 372 and saprotrophs (Bending 2003) or to water consumption by MF that reduces the 373 activity of saprotrophs (Leifheit et al. 2015). Again, more studies will be needed to 374 better grasp the role of MF in green roof or wall ecosystems, and especially identify 375 the fungal traits that best promote plant performance in these systems (Table 1). For 376 now, data are very scarce. We know that fungal colonization (John et al. 2014), as 377 well as taxonomic richness (McGuire et al. 2013) can be high in those systems. 378 However, we still lack studies identifying the impact of MF on green roof/wall plants, 379 and the optimal strains to use as inoculum (McGuire et al. 2015). Studies will also be 380 needed to better understand the nature of the interactions between MF and the 381 substrate microbiome, and their impact on plants: these interactions could be 382 synergistic and provide even more benefits to host plants, but conversely, they could 
383 be antagonistic and lead to a reduced plant performance (e.g., Molineux et al. 2014)

384 or survival.

\section{Conclusion}

From what is presented in this mini-review, in many cases the use of inocula containing MF seems to be promising in assisting phytotechnologies. However, for certain phytotechnologies (e.g., TW, green roofs and walls), there is a lack of data comparing ecosystem services with or without $\mathrm{MF}$, which calls for more empirical work. Also, in some cases, MF may prove to be disadvantageous to phytotechnological applications. For example, MF may reduce plant uptake of metals, and thus delay phytoextraction. Similarly, under severe nutrient limitations, MF may decrease nutrient transfer to hosts by first satisfying their own nutritional needs 399 addressed in future research:

1- A mechanistic framework is needed to identify the fungal traits required to provide a given ecosystem service for each phytotechnological application (Table 1). Only such a trait-based approach will allow a predictable application of MF in various applied systems. This is especially true for phytoremediation, where it is commonly found that stress-adapted fungal strains are better in promoting plant 
performance in stressful systems (e.g., Cabello et al. 1999): we thus need to identify what traits allow for stress adaptation. Likewise, for TW, we could study natural analogous systems (i.e., natural wetlands) to investigate fungal traits associated with flooded, nutrient-rich systems. Surface or thin forest soils could provide cues about the fungal traits associated with organic substrates prone to drying (i.e., green roofs and walls). As a whole, the need to better predict the utility of MF in phytotechnologies further emphasizes the need for a trait-based approach in fungal ecology, pointed out previously (e.g., Chagnon et al. 2013; Aguilar-Trigueros et al. 2014; Rillig et al. 2015; Treseder and Lennon 2015). Such an approach will require a significant amount of work in highly controlled systems, where fungal traits of individual species can be measured. However, we also stress that care must be taken when studying phytotechnologies in simplified systems. For example, it is well-known that environmental pollutants are typically not homogeneously distributed in soil profiles, and MF could avoid stress in nature by preferentially placing biomass in less stressful soil microsites: pot-based experiments with well-mixed substrates cannot meaningfully address this issue.

2- Another challenge is the production of large quantities of fungal inoculum. While in vitro cultivation allows the mass-production of clean AM fungal propagules, easily extracted and free of contaminating microorganisms, only a few species can be successfully produced using this method ( 5\%, Declerck et al. 2005). On the other hand, while many identified AM fungal species can be pot-propagated, optimal conditions for inoculum production are quite variable among species: 
different fungi prefer different hosts (Struble and Skipper 1988; Dodd et al. 1990; Bever et al. 1996), different nutrient concentrations (Egerton-Warburton et al. 2007), or different soil textures (Lekberg et al. 2007). Here, again, more research linking fungal traits to environmental conditions could be useful, and it will allow more predictability in the identification of the optimal growing conditions for a

fungus based on its traits. Moreover, another characteristic that should be considered for inoculum production is its adaptability to changing abiotic conditions: it may be useful to develop multispecies inocula that not only include the most efficient strains to provide a given service under a given environmental context, but also include a set of functionally complementary strains that may be more resilient and/or resistant to environmental fluctuations, as expected under an insurance hypothesis scenario (Yachi and Loreau 1999). More fundamental research on the plasticity of mycorrhizal fungal traits (Johnson et al. 2012; Behm and Kiers 2014) and their evolution (e.g., Angelard et al. 2010) will also provide crucial knowledge on our eventual ability to not only screen for best fungal inocula, but purposedly breed for fungal strains bearing specifically desired traits (Angelard and Sanders 2011).

3- We also need to better identify collateral benefits derived from the use of MF in phytotechnologies. For example, MF may not only improve the ecosystem service that we specifically aim at maximizing (e.g., water retention in green roofs, extraction of metals in phytoremediation), they may also provide additional services. For example, there is evidence that MF can promote plant community 
452

453

454

455

456

457

458

diversity in some contexts (e.g., Grime et al. 1987; van der Heijden et al. 1998; Urcelay and Diaz 2003), and limit the success of invasive plants (e.g., Seifert et al. 2009; Vogelsang and Bever 2009). MF could thus provide an additional, parallel tool in conservation biology.

4- Empirical results linking MF to the efficiency of phytotechnological applications often show very contrasted results, and this may be due, at least in part, to a lack of concertation in methodological approaches. It might be useful to improve coordination among research groups to develop more standardised approaches to conduct controlled experiments involving MF.

As a whole, there is no doubt that MF are part of the equation for the future of phytotechnologies, and the adoption of a trait-based approach will greatly improve our predictive power in this regard. Conversely, the trait-based study of these stressful, anthropogenic environments may provide new insights regarding phenotypic plasticity and the evolution of stress tolerance in microorganisms.

The authors gratefully acknowledge the financial support of the Natural Sciences and Engineering Council of Canada (NSERC)-Hydro-Québec Industrial Research Chair in phytotechnology (held by Jacques Brisson). 
476

477

478

479

480

481

482

483

484

485

486

487

488

489

490

491

492

493

494

495

496

497

498

499

500

501

502

503

504

505

506

507

508

509

Affholder, M.C., Pricop, A.D., Laffont-Schwob, I., Coulomb, B., Rabier, J., Borla, A., Demelas, C., and Prudent, P. 2014. As, Pb, Sb, and Zn transfer from soil to root of wild rosemary: Do native symbionts matter? Plant and Soil, 382(1-2): 219-236. doi:10.1007/s11104-014-2135-4.

Aguilar-Trigueros, C.A., Hempel, S., Powell, J.R., Anderson, I.C., Antonovics, J., Bergmann, J., Cavagnaro, T.R., Chen, B., Hart, M.M., Klironomos, J., Petermann, J.S., Verbruggen, E., Veresoglou, S.D., and Rillig, M.C. 2015. Branching out: Towards a trait-based understanding of fungal ecology. Fungal Biol. Rev. 29(1): 3441. doi:10.1016/j.fbr.2015.03.001.

Alkorta, I., and Garbisu, C. 2001. Phytoremediation of organic contaminants in soils. Bioresour. Technol. 79(3): 273-276. doi:10.1016/S0960-8524(01)00016-5.

Almeida-Rodriguez, A.M., Gomes, M.P., Loubert-Hudon, A., Joly, S., and Labrecque, M. 2016. Symbiotic association between Salix purpurea L. and Rhizophagus irregularis: Modulation of plant responses under copper stress. Tree Physiol. 36(4): 407-420. doi:10.1093/treephys/tpv119.

Anderson, T.A., Kruger, E.L., and Coats, J.R. 1994. Enhanced degradation of a mixture of three herbicides in the rhizosphere of a herbicide-tolerant plant. Chemosphere, 28(8): 1551-1557. doi:10.1016/0045-6535(94)90248-8.

Angelard, C., and Sanders, I.R. 2011. Effect of segregation and genetic exchange on arbuscular mycorrhizal fungi in colonization of roots. New Phytol. 189(3): 652-657. doi: $10.1111 / \mathrm{j} .1469-8137.2010 .03602 . x$

Angelard, C., Colard, A., Niculita-Hirzel, H., Croll, D., and Sanders, I.R. 2010. Segregation in a mycorrhizal fungus alters rice growth and symbiosis-specific gene transcription. Curr. Biol. 20(13): 1216-1221. doi:10.1016/j.cub.2010.05.031.

Audet, P., and Charest, C. 2007. Heavy metal phytoremediation from a meta-analytical perspective. Environ. Pollut. 147(1): 231-237. doi:10.1016/j.envpol.2006.08.011.

Auge, R.M. 2001. Water relations, drought and vesicular-arbuscular mycorrhizal symbiosis. Mycorrhiza, 11(1): 3-42. doi:10.1007/s005720100097.

Auzet, A.V., Le Bissonnais, Y., and Souchère, V. 2006. France. In Soil erosion in Europe. Edited by J. Boardman, and J. Poesen. Wiley, Chichester. pp.369-383

Bahr, A., Ellström, M., Akselsson, C., Ekblad, A., Mikusinska, A., and Wallander, H. 2013. Growth of ectomycorrhizal fungal mycelium along a Norway spruce forest 
nitrogen deposition gradient and its effect on nitrogen leakage. Soil Biol. Biochem. 59: 38-48. doi:10.1016/j.soilbio.2013.01.004.

Behm, J.E., and Kiers, E.T. 2014. A phenotypic plasticity framework for assessing intraspecific variation in arbuscular mycorrhizal fungal traits. J. Ecol. 102(2): 315327. doi:10.1111/1365-2745.12194.

Bellion, M., Courbot, M., Jacob, C., Blaudez, D., and Chalot, M. 2006. Extracellular and cellular mechanisms sustaining metal tolerance in ectomycorrhizal fungi. FEMS Microbiol. Lett. 254(2): 173-181. doi:10.1111/j.1574-6968.2005.00044.x.

Bending, G.D. 2003. Litter decomposition, ectomycorrhizal roots and the "Gadgil" effect. New Phytol. 158: 228-229. doi:10.1046/j.1469-8137.2003.00753.x.

Bever, J.D., Morton, J.B., Antonovics, J., and Schultz, P. a. 1996. Host-dependent sporulation and species diversity of arbuscular mycorrhizal fungi in a mown grassland. J. Ecol. 84(1): 71-82. doi:10.2307/2261701.

Blanco-Canqui, H., and Lal, R. 2010. Principles of soil conservation and management. Springer, New York.

Braun-Lüllemann, A., Hüttermann, A., and Majcherczyk, A. 1999. Screening of ectomycorrhizal fungi for degradation of polycyclic aromatic hydrocarbons. Appl. Microbiol. Biotechnol. 53(1): 127-132. doi:10.1007/s002530051625.

Brisson, J., and F. Chazarenc. 2009. Maximizing pollutant removal in constructed wetlands: should we pay more attention to macrophyte species selection? Sci. Total Environ. 407: 3923-3930

Brix, H. 1997. Do macrophytes play a role in constructed treatment wetlands? Wat. Sci. Technol. 35(5): 11-17. doi:10.1016/S0273-1223(97)00047-4.

Burghelea, C., Zaharescu, D.G., Dontsova, K., Maier, R., Huxman, T., and Chorover, J. 2015. Mineral nutrient mobilization by plants from rock: influence of rock type and arbuscular mycorrhiza. Biogeochemistry, 124(1-3): 187-203. doi:10.1007/s10533015-0092-5.

Burke, R.M., and Cairney, J.W.G. 2002. Laccases and other polyphenol oxidases in ectoand ericoid mycorrhizal fungi. Mycorrhiza, 12(3): 105-116. doi:10.1007/s00572002-0162-0.

Cabello, M. N. 1999. Effectiveness of indigenous arbuscular mycorrhizal fungi (AMF) isolated from hydrocarbon polluted soils. J. Basic Microbiol. 39(2) : 89-95. doi: 10.1002/(SICI)1521-4028(199905)39:2<89::AID-JOBM89>3.0.CO;2-D. 
Cairney, J.W.G. 1991. Rhizomorphs: Organs of exploration or exploitation? Mycologist, 5(1): 5-10. doi: 10.1016/S0269-915X(09)80325-X

Cantelmo Jr, A.J., and Ehrenfeld, J. G. 1999. Effects of microtopography on mycorrhizal infection in Atlantic white cedar (Chamaecyparis thyoides (L.) Mills.). Mycorrhiza, 8(4): 175-180. doi: 10.1007/s005720050231

Chagnon, P.L., Bradley, R.L., and Klironomos, J.N. 2015. Trait-based partner selection drives mycorrhizal network assembly. Oikos, 124(12): 1609-1616. doi:10.1111/oik.01987.

Chagnon, P.L., Bradley, R.L., Maherali, H., and Klironomos, J.N. 2013. A trait-based framework to understand life history of mycorrhizal fungi. Trends Plant Sci 18(9): 484-491. doi:10.1016/j.tplants.2013.05.001.

Clemens, S. 2006. Toxic metal accumulation, responses to exposure and mechanisms of tolerance in plants. Biochimie, 88(11): 1707-19. doi:10.1016/j.biochi.2006.07.003.

Colpaert, J. V., Wevers, J.H.L., Krznaric, E., and Adriaensen, K. 2011. How metaltolerant ecotypes of ectomycorrhizal fungi protect plants from heavy metal pollution. Ann. For. Sci. 68(1): 17-24. doi:10.1007/s13595-010-0003-9.

Confer, S.R., and Niering, W.A. 1992. Comparison of created and natural freshwater emergent wetlands in Connecticut (USA). Wetl. Ecol. Manag. 2(3): 143-156. doi:10.1007/BF00215321.

Corgié, S.C., Fons, F., Beguiristain, T., and Leyval, C. 2006. Biodegradation of phenanthrene, spatial distribution of bacterial populations and dioxygenase expression in the mycorrhizosphere of Lolium perenne inoculated with Glomus mosseae. Mycorrhiza, 16(3): 207-212. doi:10.1007/s00572-006-0049-6.

Cornwell, W.K., Bedford, B.L., and Chapin, C.T. 2001. Occurrence of arbuscular mycorrhizal fungi in a phosphorus-poor wetland and mycorrhizal response to phosphorus fertilization. Am. J. Bot. 88(10): 1824-1829.

Daghino, S., Martino, E., and Perotto, S. 2016. Model systems to unravel the molecular mechanisms of heavy metal tolerance in the ericoid mycorrhizal symbiosis. Mycorrhiza, 26(4): 263-274. doi:10.1007/s00572-015-0675-y.

Declerck, S., Séguin, S., and Dalpé, Y. 2005. The monoxenic culture of arbuscular mycorrhizal fungi as a tool for germplasm collections. In In vitro culture of mycorrhizas, Edited by S. Declerck, D.G. Strullu, and J.A. Fortin. Springer, New York. pp.17-30. 
De Deyn, G.B., Cornelissen, J.H.C., and Bardgett, R.D. 2008. Plant functional traits and soil carbon sequestration in contrasting biomes. Ecol. lett. 11(5): 516-531. doi:10.1111/j.1461-0248.2008.01164.x.

de la Providencia, I.E., Stefani, F.O.P., Labridy, M., St-Arnaud, M., and Hijri, M. 2015. Arbuscular mycorrhizal fungal diversity associated with Eleocharis obtusa and Panicum capillare growing in an extreme petroleum hydrocarbon-polluted sedimentation basin. FEMS Microbiol. Lett. 362(12). doi:10.1093/femsle/fnv081.

de Santisteban, L.M., Casalí, J., and López, J.J. 2006. Assessing soil erosion rates in cultivated areas of Navarre (Spain). Earth Surf. Process. Landforms, 31(4): 487506. doi:10.1002/esp.1281.

Dixon, R., Rao, M., and Garg, V. 1994. Water relations and gas exchange of mycorrhizal Leucaena leucocephala seedlings. J. Trop. For. Sci. 6(4): 542-552. Available from http://www.jstor.org/stable/43581779.

Dodd, J.C., Arias, I., Koomen, I., and Hayman, D.S. 1990. The management of populations of vesicular-arbuscular mycorrhizal fungi in acid-infertile soils of a savanna ecosystem - II. The effects of pre-crops on the spore populations of native and introduced VAM-fungi. Plant and Soil, 122(2): 241-247.

Drew, E.A., Murray, R.S., Smith, S.E., and Jakobsen, I. 2003. Beyond the rhizosphere: Growth and function of arbuscular mycorrhizal external hyphae in sands of varying pore sizes. Plant and Soil, 251(1): 105-114. doi:10.1023/A:1022932414788.

Egerton-Warburton, L.M., Johnson, N.C., and Allen, E.B. 2007. Mycorrhizal community dynamics following nitrogen fertilization: A cross-site test in five grasslands. Ecol. Monogr. 77(4): 527-544. doi:10.1890/06-1772.1.

Estrada-Luna, A., and Davies, F.T. 2003. Arbuscular mycorrhizal fungi influence water relations, gas exchange, abscisic acid and growth of micropropagated chile ancho pepper (Capsicum annuum) plantlets during acclimatization and postacclimatization. J. Plant Physiol. 160: 1073-1083. doi:10.1078/0176-1617-00989.

Fester, T. 2013. Arbuscular mycorrhizal fungi in a wetland constructed for benzene-, methyl tert-butyl ether- and ammonia-contaminated groundwater bioremediation. Microb. Biotechnol. 6(1): 80-84. doi:10.1111/j.1751-7915.2012.00357.x.

Franco-Correa, M., Quintana, A., Duque, C., Suarez, C., Rodríguez, M.X., and Barea, J.M. 2010. Evaluation of actinomycete strains for key traits related with plant growth promotion and mycorrhiza helping activities. Appl. Soil Ecol. 45(3): 209217. doi:10.1016/j.apsoil.2010.04.007.

Gadgil, R.L., and Gadgil, P.D. 1971. Mycorrhiza and litter decomposition. Nature, 233: 133. 
612

613

614

615

616

617

618

619

620

621

622

623

624

625

626

627

628

629

630

631

632

633

634

635

636

637

638

639

640

641

642

643

644

645

646

647

Gamalero, E., and Glick, B.R. 2012. Plant growth-promoting bacteria and metals phytoremediation. In Phytotechnologies: Remediation of environmental contaminants. Edited by N.A. Anjum, M.E. Pereira, I. Ahmad, A.C. Duarte, S. Umar, and N.A. Khan. Taylor and Francis, New York. pp. 361-376.

Genney, D.R., Alexander, I.J., Killham, K., and Meharg, A.A. 2004. Degradation of the polycyclic aromatic hydrocarbon $(\mathrm{PAH})$ fluorene is retarded in a Scots pine ectomycorrhizosphere. New Phytol. 163(3): 641-649. doi:10.1111/j.14698137.2004.01131.x.

González-Chávez, M.C., Carrillo-González, R., Wright, S.F., and Nichols, K.A. 2004. The role of glomalin, a protein produced by arbuscular mycorrhizal fungi, in sequestering potentially toxic elements. Environ. Pollut. 130(3): 317-323. doi:10.1016/j.envpol.2004.01.004.

Grime, J.P., Mackey, J.M.L., Hillier, S.H., and Read, D.J. 1987. Floristic diversity in a model system using experimental microcosms. Nature, 328(30): 420-422. doi:10.1038/328420a0.

Hage-Ahmed, K., Moyses, A., Voglgruber, A., Hadacek, F., and Steinkellner, S. 2013. Alterations in root exudation of intercropped tomato mediated by the arbuscular mycorrhizal fungus Glomus mosseae and the soilborne pathogen Fusarium oxysporum f.sp. lycopersici. J. Phytopathol. 161(11-12): 763-773. doi:10.1111/jph.12130.

Haselwandter, K., and Winkelmann, G. 2002. Ferricrocin - An ectomycorrhizal siderophore of Cenococcum geophilum. BioMetals, 15(1): 73-77. doi:10.1023/A:1013188823076.

Haselwandter, K., Passler, V., Reiter, S., Schmid, D.G., Nicholson, G., Hentschel, P., Albert, K., and Winkelmann, G. 2006. Basidiochrome - A novel siderophore of the orchidaceous mycorrhizal fungi Ceratobasidium and Rhizoctonia spp. BioMetals, 19(3): 335-343. doi:10.1007/s10534-006-6986-x.

Hassan, S.E., Labrecque, M., St-Arnaud, M. and Hijri, M. 2010. Prospects of plants and arbuscular mycorrhizal fungi in phytoremediation of heavy metal contaminated soil. In Mycorrhizal biotechnology, Edited by D. Thangadurai, C.A. Busso, and M. Hijri. Taylor and Francis, New York. pp. 152-177.

Hassan, S.E., Hijri, M., and St-Arnaud, M. 2013. Effect of arbuscular mycorrhizal fungi on trace metal uptake by sunflower plants grown on cadmium contaminated soil. New. Biotechnol. 30(6): 780-787. doi:10.1016/j.nbt.2013.07.002.

Hassan, S.E.D., Bell, T.H., Stefani, F.O.P., Denis, D., Hijri, M., and St-Arnaud, M. 2014. Contrasting the community structure of arbuscular mycorrhizal fungi from 

hydrocarbon-contaminated and uncontaminated soils following willow (Salix spp. L.) planting. PLoS One, 9(7). doi:10.1371/journal.pone.0102838.

Hetrick, B.A.D., Leslie, J.F., Wilson, G.T., and Kitt, D.G. 1988. Physical and topological assessment of effects of a vesicular-arbuscular mycorrhizal fungus on root architecture of big bluestem. New Phytol. 110(1): 85-96. doi:10.1111/j.14698137.1988.tb00240.x.

Hoyano, A. 1988. Climatological uses of plants for solar control and the effects on the thermal environment of a building. Energy Build. 11(1-3): 181-199. doi:10.1016/0378-7788(88)90035-7.

Infante, C., Hernandez-Valencia, I., Lopez, L., and Toro, M. 2012. Phytoremediation of petroleum-contaminated soils in Venezuela. In Phytotechnologies: Remediation of environmental contaminants. Edited by N.A. Anjum, M.E. Pereira, I. Ahmad, A.C. Duarte, S. Umar, and N.A. Khan. Taylor and Francis, New York. pp.293-308.

Jansa, J., Bukovská, P., and Gryndler, M. 2013. Mycorrhizal hyphae as ecological niche for highly specialized hypersymbionts - or just soil free-riders? Front. Plant Sci. 4(May): 134. doi:10.3389/fpls.2013.00134.

John, J., Lundholm, J., and Kernaghan, G. 2014. Colonization of green roof plants by mycorrhizal and root endophytic fungi. Ecol. Eng. 71: 651-659. doi:10.1016/j.ecoleng.2014.08.012.

Johnson, D., Martin, F., Cairney, J.W.G., and Anderson, I.C. 2012. The importance of individuals: Intraspecific diversity of mycorrhizal plants and fungi in ecosystems. New Phytol. 194(3): 614-628. doi:10.1111/j.1469-8137.2012.04087.x.

Johnson, N.C. 1993. Can fertilization of soil select less mutualistic mycorrhizae? Ecol. Appl. 3(4): 749-757. doi:10.2307/1942106.

Johnson, N.C., Rowland, D.L., Corkidi, L., Egerton-Warburton, L.M., and Allen, E.B. 2003. Nitrogen enrichment alters mycorrhizal allocation at five mesic to semiarid grasslands. Ecology, 84(7): 1895-1908. doi:Doi 10.1890/00129658(2003)084[1895:Neamaa]2.0.Co;2.

Joner, E.J., Briones, R., and Leyval, C. 2000. Metal-binding capacity of arbuscular mycorrhizal mycelium. Plant and Soil, 226(2): 227-234. doi:10.1023/A:1026565701391.

Jongmans, A.G., Lundström, U.S., van Breemen, N., van Hees, P.A.W., Finlay, R.D., Srinivasan, M., Unestam, T., Giesler, R., Melkerud, P.A., and Olsson, M. 1997. Rock-eating fungi. Nature, 389(6652): 682-683. doi:10.1038/39493. 
682

683

684

685

686

687

688

689

690

691

692

693

694

695

696

697

698

699

700

701

702

703

704

705

706

707

708

709

710

711

712

713

714

715

716

717

718

Kohler, J., Roldán, A., Campoy, M., and Caravaca, F. 2017. Unraveling the role of hyphal networks from arbuscular mycorrhizal fungi in aggregate stabilization of semiarid soils with different textures and carbonate contents. Plant and Soil, 410(1): 1-9. doi:10.1007/s11104-016-3001-3.

Koller, R., Rodriguez, A., Robin, C., Scheu, S., and Bonkowski, M. 2013. Protozoa enhance foraging efficiency of arbuscular mycorrhizal fungi for mineral nitrogen from organic matter in soil to the benefit of host plants. New Phytol. 199(1): 203211. doi:10.1111/nph.12249.

Krishnamoorthy, R., Kim, C.G., Subramanian, P., Kim, K.Y., Selvakumar, G., and Sa, T.M. 2015. Arbuscular mycorrhizal fungi community structure, abundance and species richness changes in soil by different levels of heavy metal and metalloid concentration. PLoS One, 10(6): e0128784. doi:UNSPe0128784\r10.1371/journal.pone.0128784.

Lacercat-Didier, L., Berthelot, C., Foulon, J., Errard, A., Martino, E., Chalot, M., and Blaudez, D. 2016. New mutualistic fungal endophytes isolated from poplar roots display high metal tolerance. Mycorrhiza, 26(7): 657-671. doi:10.1007/s00572-016$0699-\mathrm{y}$.

Le Tacon, F., Skinner, F.A., and Mosse, B. 1983. Spore germination and hyphal growth of a vesicular-arbuscular mycorrhizal fungus, Glomus mosseae (Gerdemann and Trappe), under decreased oxygen and increased carbon dioxide concentrations. Can. J. Microbiol. 29(10): 1280-1285. doi:10.1139/m83-200.

Leake, J., Johnson, D., Donnelly, D., Muckle, G., Boddy, L., and Read, D. 2004. Networks of power and influence: the role of mycorrhizal mycelium in controlling plant communities and agroecosystem functioning. Can. J. Bot. 82: 1016-1045. doi:10.1139/b04-060.

Leifheit, E.F., Verbruggen, E., and Rillig, M.C. 2015. Arbuscular mycorrhizal fungi reduce decomposition of woody plant litter while increasing soil aggregation. Soil Biol. Biochem. 81: 323-328. doi:10.1016/j.soilbio.2014.12.003.

Leigh, J., Hodge, A., and Fitter, A.H. 2009. Arbuscular mycorrhizal fungi can transfer substantial amounts of nitrogen to their host plant from organic material. New Phytol. 181(1): 199-207. doi:10.1111/j.1469-8137.2008.02630.x.

Lekberg, Y., Koide, R.T., Rohr, J.R., Aldrich-Wolfe, L., and Morton, J.B. 2007. Role of niche restrictions and dispersal in the composition of arbuscular mycorrhizal fungal communities. J. Ecol. 95(1): 95-105. doi:10.1111/j.1365-2745.2006.01193.x.

Lenoir, I., Lounes-Hadj Sahraoui, A., and Fontaine, J. 2016. Arbuscular mycorrhizal fungal-assisted phytoremediation of soil contaminated with persistent organic pollutants: a review. Eur. J. Soil Sci. 67(5): 624-640. doi:10.1111/ejss.12375. 
Leung, H.M., Wang, Z.W., Ye, Z.H., Yung, K.L., Peng, X.L., and Cheung, K.C. 2013. Interactions between arbuscular mycorrhizae and plants in phytoremediation of metal-contaminated soils: A review. Pedosphere, 23(5): 549-563. doi:10.1016/S1002-0160(13)60049-1.

Leyval, C., and Joner, E.J. 2001. Bioavailbility of heavy metals in the mycorrhizosphere. In Bioavailability of heavy metals in the mycorrhizosphere: Trace elements in rhizosphere. Edited by G.R. Goran, W.W. Wenzel, and E. Lombi. CRC Press, New York. pp. 165-185.

Lilleskov, E.A., Bruns, T.D., Dawson, T.E., and Camacho, F.J. 2009. Water sources and controls on water-loss rates of epigeous ectomycorrhizal fungal sporocarps during summer drought. New Phytol. 182(2): 483-494. doi:10.1111/j.14698137.2009.02775.x.

Lindahl, B.D., and Tunlid, A. 2015. Ectomycorrhizal fungi - potential organic matter decomposers, yet not saprotrophs. New Phytol. 205(4):1443-1447. doi:10.1111/nph.13201.

Lingua, G., Copetta, A., Musso, D., Aimo, S., Ranzenigo, A., Buico, A., Gianotti, V., Osella, D., and Berta, G. 2015. Effect of arbuscular mycorrhizal and bacterial inocula on nitrate concentration in mesocosms simulating a wastewater treatment system relying on phytodepuration. Environ. Sci. Pollut. Res. 22(23): 18616-18625. doi:10.1007/s1 1356-015-5502-7.

Liu, A., and Dalpé, Y. 2009. Reduction in soil polycyclic aromatic hydrocarbons by arbuscular mycorrhizal leek plants. Int. J. Phytoremed. 11(1): 39-52. doi: $10.1080 / 15226510802363444$.

Lopes, L.D., Pereira e Silva, M. de C., and Andreote, F.D. 2016. Bacterial abilities and adaptation toward the rhizosphere colonization. Front. Microbiol. 7(AUG). doi:10.3389/fmicb.2016.01341.

Mangkoedihardjo, S. 2007. Phytotechnology integrity in environmental sanitation for sustainable development. J. Appl. Sci. Res. 3(10): 1037-1044.

Marques, A.P.G.C., Oliveira, R.S., Samardjieva, K.A., Pissarra, J., Rangel, A.O.S.S., and Castro, P.M.L. 2007. Solanum nigrum grown in contaminated soil: effect of arbuscular mycorrhizal fungi on zinc accumulation and histolocalisation. Environ. Pollut. 145(3): 691-699. doi:10.1016/j.envpol.2006.06.029.

Materechera, S.A., Kirby, J.M., Alston, A.M., and Dexter, A.R. 1994. Modification of soil aggregation by watering regime and roots growing through beds of large aggregates. Plant and Soil, 160(1): 57-66. doi:10.1007/BF00150346. 
754

755

756

757

758

759

760

761

762

763

764

765

766

767

768

769

770

771

772

773

774

775

776

777

778

779

780

781

782

783

784

785

786

787

788

Mathur, N., and Vyas, A. 1995. Influence of va mycorrhizae on net photosynthesis and transpiration of Ziziphus mauritiana. J. Plant Physiol. 147(3-4): 328-330. doi:10.1016/S0176-1617(11)82161-9.

McGuire, K.L., Payne, S.G., Palmer, M.I., Gillikin, C.M., Keefe, D., Kim, S.J., Gedallovich, S.M., Discenza, J., Rangamannar, R., Koshner, J.A., Massmann, A.L., Orazi, G., Essene, A., Leff, J.W., and Fierer, N. 2013. Digging the New York city skyline: soil fungal communities in green roofs and city parks. PLoS One 8(3). doi:10.1371/journal.pone.0058020.

McGuire, K.L., Payne, S.G., Orazi, G., and Palmer, M.I. 2015. Bacteria and fungi in green roof ecosystems. In Green roof ecosystems. Edited by R.K. Sutton. Springer, New York. pp. 1-26.

Merk1, N., Schultze-Kraft, R., and Infante, C. 2005. Assessment of tropical grasses and legumes for phytoremediation of petroleum-contaminated soils. Water Air. Soil Pollut. 165(4): 195-209. doi:10.1007/s11270-005-4979-y.

Middleton, E.L., and Bever, J.D. 2012. Inoculation with a native soil community advances succession in a grassland restoration. Restor. Ecol. 20(2): 218-226. doi:10.1111/j.1526-100X.2010.00752.x.

Miller, S.P. 2000. Arbuscular mycorrhizal colonization of semi-aquatic grasses along a wide hydrologic gradient. New Phytol. 145(1): 145-155. doi:10.1046/j.14698137.2000.00566.x.

Molineux, C.J., Connop, S.P., and Gange, A.C. 2014. Manipulating soil microbial communities in extensive green roof substrates. Sci. Total Environ. 493: 632-638. doi:10.1016/j.scitotenv.2014.06.045.

Moora, M., Öpik, M., Davison, J., Jairus, T., Vasar, M., Zobel, M., and Eckstein, R.L. 2016. AM fungal communities inhabiting the roots of submerged aquatic plant Lobelia dortmanna are diverse and include a high proportion of novel taxa. Mycorrhiza, 26(7): 735-745. doi:10.1007/s00572-016-0709-0.

Nguyen, H., Rineau, F., Vangrosveld, J., Cuypers, A., Colpaert, J.V., and Ruytinx, J. A novel, highly conserved metallothionein family in basidiomycete fungi and characterization of two representative SIMTa and SIMTb genes in the ectomycorrhizal fungus Suillus luteus. Environ. Microbiol. In press. doi:10.1111/1462-2920.13729

Nicolotti, G., and Egli, S. 1998. Soil contamination by crude oil: Impact on the mycorrhizosphere and on the revegetation potential of forest trees. Environ. Pollut. 99(1): 37-43. doi:10.1016/S0269-7491(97)00179-6. 
Oberndorfer, E., Lundholm, J., Bass, B., Coffman, R.R., Doshi, H., Dunnett, N., Gaffin, S., Köhler, M., Liu, K.K.Y., and Rowe, B. 2007. Green roofs as urban ecosystems: Ecological structures, functions, and services. Bioscience, 57(10): 823. doi:10.1641/B571005.

Oehl, F., Sieverding, E., Ineichen, K., Mäder, P., Wiemken, A., and Boller, T. 2009. Distinct sporulation dynamics of arbuscular mycorrhizal fungal communities from different agroecosystems in long-term microcosms. Agric. Ecosyst. Environ. 134(34): 257-268. doi:10.1016/j.agee.2009.07.008.

Paruch, A.M., Maehlum, T., Haarstad, K., and Buseth, A.G. 2016. Performance of constructed wetlands treating domestic wastewater in Norway over a quarter of a century - options for nutrient removal and recycling. In Natural and constructed wetlands. Edited by J. Vymazal. Springer, New York. pp. 41-55.

Paterson, E., Sim, A., Davidson, J., and Daniell, T.J. 2016. Arbuscular mycorrhizal hyphae promote priming of native soil organic matter mineralisation. Plant and Soil, 408(1-2): 243-254. doi:10.1007/s11104-016-2928-8.

Pimentel, D., Harvey, C., Resosudarmo, P., Sinclair, K., Kurz, D., McNair, M., Crist, S., Shpritz, L., Fitton, L., Saffouri, R., and Blair, R. 1995. Environmental and economic costs of soil erosion and conservation. Science, 267(5201): 1117-1123. doi:10.1126/science.267.5201.1117.

Piotrowski, J.S., Denich, T., Klironomos, J.N., Graham, J.M., and Rillig, M.C. 2004. The effects of arbuscular mycorrhizas on soil aggregation depend on the interaction between plant and fungal species. New Phytol. 164(2): 365-373. doi:10.1111/j.1469-8137.2004.01181.x.

Quirk, J., Andrews, M.Y., Leake, J.R., Banwart, S.A., and Beerling, D.J. 2014. Ectomycorrhizal fungi and past high $\mathrm{CO}_{2}$ atmospheres enhance mineral weathering through increased below-ground carbon-energy fluxes. Biol. Lett. 10(7): 20140375-. doi:10.1098/rsbl.2014.0375.

Reinoso, R., Torres, L.A., and Bécares, E. 2008. Efficiency of natural systems for removal of bacteria and pathogenic parasites from wastewater. Sci. Total Environ. 395(2-3): 80-86. doi:10.1016/j.scitotenv.2008.02.039.

Rillig, M.C., Aguilar-Trigueros, C.A., Bergmann, J., Verbruggen, E., Veresoglou, S.D., and Lehmann, A. 2015. Plant root and mycorrhizal fungal traits for understanding soil aggregation. New Phytol. 205(4): 1385-1388. doi:10.1111/nph.13045.

Rillig, M.C., and Mummey, D.L. 2006. Mycorrhizas and soil structure. New Phytol. 171(1): 41-53. doi:10.1111/j.1469-8137.2006.01750.x. 
824

825

826

827

828

829

830

831

832

833

834

835

836

837

838

839

840

841

842

843

844

845

846

847

848

849

850

851

852

853

854

855

856

Rillig, M.C., Wright, S.F., and Eviner, V.T. 2002. The role of arbuscular mycorrhizal fungi and glomalin in soil aggregation: comparing effects of five plant species. Plant and Soil, 238(2): 325-333. doi:10.1023/a:1014483303813.

Robertson, S.J., McGill, B.W., Massicotte, H.B., and Rutherford, P.M. 2007. Petroleum hydrocarbon contamination in boreal forest soils: a mycorrhizal ecosystems perspective. Biol. Rev. Camb. Philos. Soc. 82(2): 213-240. doi: 10.1111/j.1469185X.2007.00012.x

Schmalenberger, A., Duran, A.L., Bray, W., Bridge, J., Bonneville, S., Benning, L.G., Romero-Gonzalez, M.E., Leake, J.R., and Banwart, S. A. 2015. Oxalate secretion by ectomycorrhizal Paxillus involutus is mineral-specific and controls calcium weathering from minerals. Sci. Rep. 5(January): 12187. doi:10.1038/srep12187.

Scholz, M., Höhn, P., and Minall, R. 2002. Mature experimental constructed wetlands treating urban water receiving high metal loads. Biotechnol. Prog. 18(6): 12571264. doi:10.1021/bp0200503.

Schuler, R., and Haselwandter, K. 1988. Hydroxamate siderophore production by ericoid mycorrhizal fungi. J. Plant Nutr. 11(6): 907-913. doi: 10.1080/01904168809363855

Seguel, A., Cumming, J.R., Klugh-Stewart, K., Cornejo, P., and Borie, F. 2013. The role of arbuscular mycorrhizas in decreasing aluminium phytotoxicity in acidic soils: A review. Mycorrhiza, 23(3): 167-183. doi:10.1007/s00572-013-0479-x.

Seifert, E.K., Bever, J.D., and Maron, J.L. 2009. Evidence for the evolution of reduced mycorrhizal dependence during plant invasion. Ecology, 90(4): 1055-1062. doi:10.1890/08-0419.1.

Sikes, B.A., Cottenie, K., and Klironomos, J.N. 2009. Plant and fungal identity determines pathogen protection of plant roots by arbuscular mycorrhizas. J. Ecol. 97(6): 1274-1280. doi: 10.1111/j.1365-2745.2009.01557.x

Smith, S.E., and Read, D.J. 2008. Mycorrhizal Symbiosis. Academic Press. New York.

Struble, J.E., and Skipper, H.D. 1988. Vesicular-arbuscular mycorrhizal fungal spore production as influenced by plant species. Plant and Soil, 109(2): 277-280.

Sutton, R.K. 2015. Introduction to green roof ecosystems. In Green roof ecosystems. Edited by R.K. Sutton. Springer, New York. pp. 1-26.

Takaya, N. 2009. Response to hypoxia, reduction of electron acceptors, and subsequent survival by filamentous fungi. Biosci. Biotechnol. Biochem. 73(1): 1-8. doi:10.1271/bbb.80487. 
Thormann, M.N. 2006. Diversity and function of fungi in peatlands: a carbon cycling perspective. Can. J. Soil Sci. 5(October 2004): 281-293. doi:10.4141/S05-082.

Tisdall, J.M. 1994. Possible role of soil-microorganisms in aggregation in soils. Plant and Soil, 159(1): 115-121. doi:10.1007/BF00000100.

Toljander, J.F., Lindahl, B.D., Paul, L.R., Elfstrand, M., and Finlay, R.D. 2007. Influence of arbuscular mycorrhizal mycelial exudates on soil bacterial growth and community structure. FEMS Microbiol. Ecol. 61(2): 295-304. doi:10.1111/j.15746941.2007.00337.x.

Treseder, K.K., and Lennon, J.T. 2015. Fungal traits that drive ecosystem dynamics on land. Microbiol. Mol. Biol. Rev. 79(2): 243-262. doi:10.1128/MMBR.00001-15.

Urcelay, C., and Díaz, S. 2003. The mycorrhizal dependence of subordinates determines the effect of arbuscular mycorrhizal fungi on plant diversity. Ecol. lett. 6(5): 388391. doi:10.1046/j.1461-0248.2003.00444.x.

van de Voorde, T.F.J., van der Putten, W.H., Gamper, H.A., Gera Hol, W.H., and Martijn Bezemer, T. 2010. Comparing arbuscular mycorrhizal communities of individual plants in a grassland biodiversity experiment. New Phytol. 186(3): 746-754. doi:10.1111/j.1469-8137.2010.03216.x.

van der Heijden, M.G.A., Klironomos, J.N., Ursic, M., Moutoglis, P., Streitwolf-Engel, R., Boller, T., Sanders, I.R., and Wiemken, A. 1998. Mycorrhizal fungal diversity determines plant biodiversity, ecosystem variability and productivity. Nature, 396(6706): 69-72. doi:10.1038/23932.

Varkey, M., Lal, N., and Khan, Z.H. 2012. Phytoremediation: Strategies to enhance the potential for toxic metal remediation of Brassica oilseed species. In Phytotechnologies: Remediation of environmental contaminants. Edited by N.A. Anjum, M.E. Pereira, I. Ahmad, A.C. Duarte, S. Umar, and N.A. Khan. Taylor and Francis, New York. pp.293-308.

Verbruggen, E., Jansa, J., Hammer, E.C., and Rillig, M.C. 2016. Do arbuscular mycorrhizal fungi stabilize litter-derived carbon in soil? J. Ecol. 104(1): 261-269. doi:10.1111/1365-2745.12496.

Vymazal, J. 2011. Plants used in constructed wetlands with horizontal subsurface flow: a review. Hydrobiologia, 674: 133-156

Vivas, A., Biro, B., Németh, T., Barea, J.M., and Azcon, R. 2006. Nickel-tolerant Brevibacillus brevis and arbuscular mycorrhizal fungus can reduce metal acquisition and nickel toxicity effects in plant growing in nickel supplemented soil. Soil Biol. Biochem. 38(9): 2694-2704. doi:10.1016/j.soilbio.2006.04.020. 
892

893

894

895

896

897

898

899

900

901

902

903

904

905

906

907

908

909

910

911

912

913

914

915

916

917
Vogelsang, K.M., and Bever, J.D. 2009. Mycorrhizal densities decline in association with normative plants and contribute to plant invasion. Ecology, 90(2): 399-407. doi:10.1890/07-2144.1.

Wang, F.Y., Lin, X.G., and Yin, R. 2007. Inoculation with arbuscular mycorrhizal fungus Acaulospora mellea decreases $\mathrm{Cu}$ phytoextraction by maize from $\mathrm{Cu}$-contaminated soil. Pedobiologia, 51(2): 99-109. doi:10.1016/j.pedobi.2007.02.003.

Wang, Y., Qiu, Q., Li, S., Xin, G., and Tam, N.F.Y. 2014. Inhibitory effect of municipal sewage on symbiosis between mangrove plants and arbuscular mycorrhizal fungi. Aquat. Biol. 20(2): 119-127. doi:10.3354/ab00550.

Winkelmann, G. 2007. Ecology of siderophores with special reference to the fungi. BioMetals, 20: 379-392. doi:10.1007/s10534-006-9076-1.

Wu, S., Zhang, X., Chen, B., Wu, Z., Li, T., Hu, Y., Sun, Y., and Wang, Y. 2016. Chromium immobilization by extraradical mycelium of arbuscular mycorrhiza contributes to plant chromium tolerance. Environ. Exp. Bot. 122: 10-18. doi:10.1016/j.envexpbot.2015.08.006.

Wu, Z., McGrouther, K., Huang, J., Wu, P., Wu, W., and Wang, H. 2014. Decomposition and the contribution of glomalin-related soil protein (GRSP) in heavy metal sequestration: field experiment. Soil Biol. Biochem. 68: 283-290. doi:10.1016/j.soilbio.2013.10.010.

Xu, Z., Ban, Y., Jiang, Y., Zhang, X., and Liu, X. 2016. Arbuscular mycorrhizal fungi in wetland habitats and their application in constructed wetland: a review. Pedosphere, 26(5): 592-617. doi:10.1016/S1002-0160(15)60067-4.

Yachi, S., and Loreau, M. 1999. Biodiversity and ecosystem productivity in a fluctuating environment: the insurance hypothesis. Proc. Natl. Acad. Sci. U. S. A. 96(4): 14631468. doi:10.1073/pnas.96.4.1463. 
918 Table 1. Mycorrhizal fungal traits likely (or known) to play a role in phytotechnological applications. We specify whether each trait is

919 expected to be relevant to arbuscular mycorrhizal (AM), ectomycorrhizal (ECM), and/or ericoid mycorrhizal (ERM) fungi. We also

920 identify the function of this trait in a phytotechnological context (i.e., why this trait would be valuable in phytotechnology).

\begin{tabular}{cc}
\hline Phytotechnology \\
\hline 1 Phytoremediation \\
i. Metals
\end{tabular}

i. Metals

AM, ECM, ERM

AM, ECM, ERM

AM, ECM, ERM

AM, ECM, ERM

AM, ECM, ERM

ECM, ERM
Production of metal-binding agents in cell walls (e.g., glomalin in AM fungi) or inside cytosol/vacuoles

(e.g., polyphosphates, glutathione, metallothioneins)

Enhanced mechanisms for free radical scavenging (e.g., superoxide dismutase)

High metal absorption rates

High, or low, metal transfer rate to plants

High rates of $\mathrm{C}$ transfer to heterotrophic soil microorganisms

Direct siderophore production
Reduce transfer to host (i.e., phytostabilization)

Function

Mitigate the stress imposed by metalmediated free radical production

Improved phytoextraction

Improved phytoextraction, or phytostabilization, respectively

Favour growth of metal-binding or metal-solubilizing microorganisms

Chelate metals
Bellio et al. 2006; Colpaert et al. 2011; Leung et al. 2013; Wu et al. 2014; Nguyen et al. in press;

Bellio et al. 2006

Janouskova et al. 2006; Colpaert et al. 2011; Wu et al. 2016

Audet and Charest 2006

Franco-Correa et al. 2010

Schuler and

Haselwandter 1988;

Haselwandter and 
ii. Organic pollutants

ECM, ERM
AM, ECM, ERM

AM, ECM, ERM

\section{Expression of laccases}

Exudation of large amounts of $\mathrm{C}$, or priming of host exudation

Enhanced nutrient transfer to hosts
Stabilization of degraded soils
Oxidation of organic pollutants

Favor the growth of microorganisms that can attack organic pollutants

Large amounts of organic pollutants can increase soil C-to-nutrients ratio, thus inducing nutrient limitation and increasing plant-microbial competition for nutrients. Plants can gain competitive advantage by receiving nutrients from mycorrhizal fungi
Burke and Cairney 2002

Toljander et al. 2007; Jansa et al. 2013; Lenoir et al. 2016

Smith and Read 2008
AM, ECM, ERM

$\mathrm{ECM}$

AM, ECM, ERM
High hyphal density and/or growth rates

Formation of long-lived rhizomorphs

Exudation of large quantities of $\mathrm{C}$
Rapidly establish a hyphal network likely to enhance aggregate formation and/or stabilization

Fungal necromass contributing to aggregate stability

Act as aggregate binding agents or promote the growth of heterotrophic microorganisms exuding binding agents
Rillig et al. 2015

Cairney 1991

Rillig et al. 2015 
AM, ECM, ERM Promotion of host root production

AM, ECM, ERM
High root density may favor initiation of macroaggregate formation and will increase amounts of $\mathrm{C}$ exuded to soils

High compatibility with hosts used in vegetation restoration practices
Symmetrical benefits derived by hosts from mycorrhizal fungi (and vice versa) will promote root and hyphal biomass production, eventually favoring aggregate formation and stabilization
Materechera et al. 1994

Middleton and Bever

2012; Chagnon et al.

2015

\section{AM, ECM, ERM Specialized electron transport chains}

AM, ECM, ERM

Promotion of host root production

AM, ECM, ERM

AM, ECM, ERM Low nutrient use efficiency

AM, ECM, ERM

Tolerance to pollutants found in wastewaters rates
Tolerate hypoxia in submerged environments

Enhance plant beneficial impacts on nutrient uptake, exudate-driven decomposition of organic matter by microorganisms, or interception of pathogens propagules

High hyphal density and/or growth As for plant roots, improve C transfer to [this study] heterotrophic microorganisms and take up nutrients

Increase nutrient consumption from wastewaters

Sustain activity even under abiotic stress
Takaya 2009

Brix 1997

[this study]

Bellio et al. 2006;

Colpaert et al. 2011; Wu

et al. 2014 
4 Green roofs and walls

$\mathrm{AM}$

$\mathrm{AM}$

$\mathrm{AM}$

AM
Fine hyphal diameter

Alter host hormonal balance (e.g., abscisic acid)

High hyphal density and/or growth rates

High water use efficiency
Improve water retention and uptake in fine soil pores

Ameliorate host tolerance to drought

Favor C transfer to heterotrophic microorganisms to prime decomposition of the organic substrate

Tolerate low water availability
Drew et al. 2003

Augé 2001

De Deyn et al. 2008;

Paterson et al. 2016

Lilleskov et al. 2009 